\title{
Predictive policing: politiewerk aan de hand van voorspellingen
}

\author{
A. de Vries en S. Smit ${ }^{*}$
}

George Orwell waarschuwt in zijn boek 1984 (Orwell 1949) voor een overheid die haar onderdanen monitort en alles in de gaten houdt. In de film Minority Report is de 'pre-crime squad' in staat om moorden te voorspellen en daders preventief op te pakken. De Nederlandse politie heeft dankzij de omvorming tot Nationale Politie toegang tot alle landelijke, regionale en lokale databronnen met betrekking tot criminaliteit en is daarmee een 'informatieorganisatie' geworden. Door verbeterde analysetechnieken, visualisatietools en computerkracht kan zij deze 'Big Data' inzetten om criminaliteit te voorspellen en op basis daarvan op te treden. Moeten we nu vrezen voor onze toekomst? Pakt de politie voortaan burgers preventief op? Worden systemen leidend? Het antwoord op al deze vragen is nee. Maar welke kant gaat het dan wel op?

\section{Interessante patronen}

Politieorganisaties over de hele wereld, en dus ook in Nederland, houden zich momenteel bezig met de ontwikkeling van predictive policing - ofwel: politiewerk doen aan de hand van voorspellingen. De reden daarvoor is dat zij beschikken over ongelofelijk veel digitale gegevens over misdaden uit het verleden, die met verfijnde algoritmen en diepe analyse een goudmijn vormen voor het voorspellen van criminaliteit. Het gevolg daarvan is dat de politie aanwezig kan zijn op plaatsen waar de kans op een volgend incident het grootst is. Daar komt bij dat

* Ir. Arnout de Vries is senior onderzoeker en adviseur op het gebied van social media en veiligheid bij TNO en auteur van het boek Social media: het nieuwe DNA. Dr. Selmar Smit is aan de Vrije Universiteit Amsterdam gepromoveerd op het onderwerp machine learning en sindsdien werkzaam als data scientist bij TNO. Dit artikel is gebaseerd op het boek Van predictive naar prescriptive policing, uitgegeven door TNO en geschreven door Selmar Smit, Arnout de Vries, Rick van der Kleij en Hans van Vliet. Dit boek is te downloaden via www.tno.nl/prescriptive-policing. 
deze hoeveelheid beschikbare data exponentieel blijft groeien als gevolg van databasekoppelingen met veiligheidspartners en het ontstaan van het 'Internet of Things', waarbij alles en iedereen aan het internet gekoppeld is ('Big Data'). Het effect van Big Data-analyses is al te zien bij commerciële bedrijven, die verbanden weten te leggen tussen bijvoorbeeld iemands aankopen, inkomen, leeftijd en postcodegebied. Ook de politie is op zoek naar dergelijke verbanden, zodat zij misdaden kan voorspellen.

In de criminologie zijn er voldoende theorieën over het denken en doen van criminelen die inzicht geven in dergelijke patronen. Zo zegt de routine activity theory dat criminelen zullen toeslaan op die locatie waar de virtuele cirkels rond criminelen en geschikte slachtoffers elkaar overlappen. Dit leidt tot de gedachte dat steeds dezelfde gebieden worden getroffen, als er geen maatregelen worden genomen. De rational choice theory gaat ervan uit dat criminelen een locatie kiezen waar de afweging tussen risico (pakkans) en buit zo gunstig mogelijk is. Volgens de crime pattern theory zullen criminelen nooit te dicht bij hun eigen huis toeslaan, maar altijd in een buurt die ze kennen, vlak bij huis, werk, sportschool of op de weg daarnaartoe. De blended theory is een combinatie van de vorige drie: een crimineel zal toeslaan op een locatie langs zijn 'activiteitenroutes', maar niet te dicht bij huis en daar waar de afweging tussen buit en pakkans positief is. Bij predictive policing worden deze theorieën vaak overboord gegooid en wordt voornamelijk gekeken naar de simpele theorie van near repeats: in de buurt van een incident zal vaak nog een incident volgen zolang er niets verandert. Hoewel dit op het eerste gezicht niet lijkt op de voorgaande theorieën zal, zolang de pakkans, buit en activiteitenroutes van criminelen niet veranderen, het effect hetzelfde zijn en zullen incidenten zich in dezelfde buurt blijven voordoen.

\section{Doorontwikkeling informatiegestuurd optreden}

Een slimme, effectieve en proactieve aanpak tegen misdaad is duidelijk beter dan achter criminelen aan hollen; rechercheren verandert in 'prerechercheren'. Predictive policing in combinatie met Big Data neemt daarom logischerwijs een enorme vlucht. En het geeft de Nationale Politie de mogelijkheid om invulling te geven aan 'meer doen met 
minder middelen'. Maar is predictive policing eigenlijk wel nieuw? $\mathrm{Nu}$ al beschikt de politie over slimme analyseteams die een enorme bijdrage leveren aan het dagelijkse politiewerk door misdaadstatistieken en andere gegevens, zoals jaargetijden, tijdstippen en locaties, te interpreteren. Dit leidt onder andere tot hotspotkaarten, waarop locaties te zien zijn waar specifieke politie-inzet nodig is. Op die manier kan de politie bijvoorbeeld haar surveillanceteams effectief inzetten. De gemeente Eindhoven gebruikt dergelijke hotspot- of inzetkaarten om de effectiviteit van de BOA's (buitengewoon opsporingsambtenaren) van Stadstoezicht te verhogen (Van Weerdt \& De Vries 2014). Brandweer Rotterdam-Rijnmond heeft de brandweerradar die voorspelt waar de volgende brand zich zal voordoen en zorgt vervolgens dat er een voertuig in de buurt is (Littooij 2015). Een nieuw computermodel van TNO wordt gebruikt om overlastsituaties in wijken te voorspellen en interventies te berekenen die het beste zouden moeten werken in de betreffende specifieke situatie (Smit 2014). De beweging die wij bij de politie zien, past dan ook in de huidige tijd waarin nieuwe mogelijkheden ontstaan door het analyseren van Big Data. Het huidige informatiegestuurd optreden van de politie (intelligence-led policing) professionaliseert en ontwikkelt zich door naar predictive policing, waarbij niet alleen gehandeld en gestuurd wordt op basis van informatie uit het verleden, maar ook gehandeld, gestuurd én geanticipeerd wordt op basis van voorspellingen. Hiervoor is sinds enige tijd het Criminaliteits Anticipatie Systeem in gebruik bij basisteams, flexteams en districten door heel Nederland.

\section{Criminaliteits Anticipatie Systeem (CAS)}

Het CAS vindt zijn oorsprong bij de politie Amsterdam. Via het programma Politie en Wetenschap ontwikkelt zij een geavanceerd plannings- en voorspellingssysteem. Diverse politiekorpsen in het land gebruiken het CAS inmiddels voor het voorspellen van high impact crimes (woninginbraak, straatroof en overvallen). Als voorbeeld gebruiken we het operationele gebied van de politie Amsterdam. Het systeem deelt dit gebied op in vakjes van 125 bij 125 meter. Gebiedjes waarvan de kans op een incident vooraf al laag kan worden ingeschat, zoals weilanden en open water, worden verwijderd. Van de overblijvende vakjes wordt een grote hoeveelheid gegevens verzameld: crimi- 
naliteitshistorie, afstand tot bekende verdachten, afstand tot de dichtstbijzijnde snelwegoprit, soort en aantal bedrijven zoals bekend bij de politie, en demografische en socio-economische gegevens van het CBS. Van elk vakje wordt op verschillende peilmomenten geregistreerd welke gegevens er op dat moment bekend zijn. Vervolgens wordt bepaald wat er in de twee weken na de peiling aan incidenten kan plaatsvinden. Er wordt kunstmatige neurale netwerktechnologie toegepast om te bepalen welke combinatie van kenmerken indicatief is voor criminaliteit in de nabije toekomst. Het resultaat is dat de vakjes op de kaart indicatief worden ingekleurd, een zogenoemde heat map, waarin hoge scores een warmere kleur krijgen.

\section{Betrouwbaarheid}

Naast het door de politie zelf ontwikkelde CAS zijn er nog diverse andere softwarepakketten op de markt. Vrijwel alle pakketten kijken naast near repeats vaak ook naar tijdsaspecten (spatiotemporele analyse) en trends zoals verplaatsingen, seizoenen, weekdagen of weekend en zelfs specifieke tijdstippen. Verder wordt er gekeken naar kenmerken als omgevingsfactoren (bijvoorbeeld demografie), weersvoorspellingen, afstanden tot vluchtwegen (aantrekkende werking) en locaties van politiebureaus (afstotende werking). Dat levert complexe formules op met tientallen parameters. Hoe betrouwbaar zijn de voorspellingen die deze formules opleveren? Kloppen ze wel? Daar is niet een direct antwoord op te geven. De betrouwbaarheid van de voorspellingen is logischerwijs ook afhankelijk van de voorspelbaarheid van de criminelen. Crimineel gedrag blijkt voor veelvoorkomende criminaliteit zoals inbraken goed te voorspellen. De mens, en dus ook de crimineel, is een gewoontedier dat succes op succes en ervaring op ervaring bouwt. Als een bepaald type woning goed te kraken valt, dan gaan ze daarmee verder. Een bekende omgeving is voor criminelen prettig, omdat zij dan een betere risico-inschatting kunnen maken en daarmee de kans op succes vergroten. Grote veranderingen in gedrag (de modus operandi) of omgeving (nieuwe 'markten') zonder directe aanleiding zijn eerder uitzondering dan regel. Rondtrekkend mobiel banditisme is echter veel lastiger te voorspellen, laat staan impulsieve misdaden zoals een crime passionnel. Toch kan in algemene zin wel de betrouwbaarheid van de voorspellingen worden geduid. 
Ten eerste is de betrouwbaarheid van een voorspelmodel afhankelijk van de hoeveelheid incidenten binnen een vakje op de kaart. Het gedrag van een individu valt moeilijk te voorspellen, maar het gemiddelde gedrag van een groep is goed mogelijk. Bedrijven als Amazon en Bol.com gebruiken ditzelfde principe om aanbevelingen te doen. Zij kunnen niet voorspellen of een individu geïnteresseerd is in een product, maar wel dat mensen met een bepaald profiel er gemiddeld vaak in geïnteresseerd zijn. Dit geldt ook voor incidenten. Doordat inbraken relatief vaak voorkomen, levert dit voldoende input op om profielen te maken en voorspellingen te doen.

Vaak weten analisten zelf al wel wat de kans is op een inbraak in een specifiek vakje. Maar als dat $80 \%$ is, wat is dan de meerwaarde van een systeem dat voorspelt dat de kans op inbraak de ene dag $75 \%$ is en de andere dag $85 \%$ ? Daarom is het belangrijk een detailleringsniveau te kiezen dat klein genoeg is om meerwaarde te hebben ten opzichte van de intuïtie van een analist. Ook moet de datahoeveelheid groot genoeg zijn om een bepaald niveau van betrouwbaarheid te halen. Blijkbaar kan het. Tijdens een test in de Verenigde Staten moesten ervaren analisten en een predictive policing-systeem aangeven in welke twintig vakjes een incident zou kunnen plaatsvinden tijdens een dienst. Het voorspelmodel had twee keer zo vaak gelijk als de analisten (Mohler e.a. 2015).

Ten tweede zijn de betrouwbaarheid en validiteit van een voorspelmodel afhankelijk van de hoeveelheid informatie die het herbergt. Met informatie bedoelen we hier niet alleen databronnen, maar ook kennis en expertise over gedrag. Zo zullen bijvoorbeeld modellen die uitgaan van near repeats (een incident zorgt voor een verhoogde kans op nog een incident in de buurt) beter werken dan modellen die dergelijke kennis niet meenemen.

Vooral dit tweede aspect lijkt een grenzeloze groei aan voorspelkracht te bevatten. Er is immers altijd wel een informatiebron te vinden die we extra kunnen toevoegen. Het eindeloos toevoegen van bronnen heeft echter niet zoveel zin, omdat de voorspelkracht op een gegeven moment niet veel meer zal verbeteren. Het gaat daarom met name om de kwaliteit van bronnen en minder om de hoeveelheid bronnen die door data-experts en analisten aan het systeem worden toegevoegd. Goede bronnen leveren continu kwalitatieve en actuele data aan het predictive policing-systeem, waardoor dit systeem voorspellingen kan 
doen op basis van 'verse' data en daarmee een accurate ondersteuning biedt voor het politiewerk.

\section{Voorspelkracht en effectiviteit}

Zelfs als we ervan uitgaan dat gedrag, met genoeg data, is te voorspellen, betekent dit echter niet dat de voorspellingen van predictive policing altijd uitkomen. Naast dat voorspellingen enkel een kans aangeven en geen vaststaand feit, komen voorspellingen niet uit omdat de politie acteert op de voorspellingen en haar surveillanceteams op basis daarvan gericht inzet. Die plotselinge aanwezigheid van één of meer agenten beïnvloedt uiteraard het gedrag van een crimineel op dat moment. Door deze efficiënte en effectieve inzet van agenten op plekken waar het ertoe doet, zullen minder misdaden worden gepleegd. Niet meer blauw op straat, maar gerichter blauw op straat is de theorie achter predictive policing. Dat dit werkt, laten de cijfers zien. In Los Angeles daalt de misdaad met $13 \%^{1}$ en in Santa Cruz daalt het aantal inbraken met $27 \%^{2}$. In Kent ligt de hitscore van de software - waarbij daadwerkelijk een misdrijf plaatsvond in een geselecteerd vakje op de kaart - bijna $60 \%$ hoger dan wanneer de vakjes handmatig gekozen werden door analisten (Kent Police 2013). In Amsterdam ligt de hitscore volgens de politie-eenheid Amsterdam-Amstelland in 2015 op $15 \%$ en het aantal near hits (een inbraak of straatroof die niet in het voorspelde vakje valt maar er net naast) ligt voor woninginbraken op $40 \%$ en voor straatroof op $60 \%$. Een pilot in Londen richt zich niet op de locatie van een misdrijf maar op de dader. Dat levert een heat list op van driehonderd namen, waarvan er zes nieuw zijn voor de politie en waarvan er vijf in de weken daarna een misdaad plegen (Basulto 2014). In Memphis loopt de algemene criminaliteit terug met $30 \%$ en het aantal geweldsmisdrijven met 15\% (Greenburg 2009). Als gevolg daarvan behoort Memphis niet meer tot de top 3 van gevaarlijkste steden in de Verenigde Staten. Volgens de politie komt dat door de juiste politie-inzet (bijvoorbeeld surveillance, auto's staande houden en undercoveroperaties) op de juiste tijd en plek (Williams 2006). Autodiefstallen daalden met $75 \%$ en inbraken in bedrijven met $67 \%$ (Perry e.a. 2013). Inmiddels heeft de politie van Memphis een Real Time 
Crime Center van \$ 3 miljoen neergezet om predictive policing een vaste plaats te geven in haar manier van werken. Volgens onderzoek van Nucleus Research levert dit centrum jaarlijks meer dan \$ 7 miljoen op (Nucleus Research 2010). Ook New York heeft een Real Time Crime Center, waar alle databases én meer dan 3.000 politiecamera's worden geanalyseerd. In Zwitserland en Duitsland is een aantal politiekorpsen Precobs-software aan het testen, het zogenoemde Pre Crime Observation System ${ }^{3}$ De politie in Noordrijn-Westfalen is daarentegen zeer kritisch over de effecten van predictive policing, omdat de positieve cijfers en gemeten effecten veelal worden geleverd door softwareleveranciers of politiekorpsen die baat hebben bij het presenteren van gunstige cijfers. In het Amerikaanse Richmond is men gestopt met deze werkwijze vanwege gebrek aan bewijs dat het zou werken (Aldax 2015). Ondanks deze kritische geluiden lijkt het erop dat criminaliteit wel degelijk goed te voorspellen is. Het staat echter nog wel in de kinderschoenen en het zijn vooral wiskundigen die zich op dit moment bezighouden met het ontwikkelen van voorspellende algoritmen. Predictive policing richt zich om die reden nu nog vooral op veelvoorkomende delicten waar een klein aantal mensen een rol in speelt (zoals veelplegers uit een buurt of rondtrekkende dadergroepen) en vermogensdelicten zoals woninginbraken en straatroof, waar vaak aangifte van wordt gedaan. Maar op termijn, als de politie beschikt over meer informatie en betere databronnen, valt te verwachten dat het systeem ook andere delicten kan voorspellen, zoals liquidaties in de onderwereld of een radicaliseringsproces. De maatschappij zal echter nooit helemaal zonder misdaad zijn en voorspellend politiewerk is geen oplossing voor alle misdaad. Het is geen panacee voor een veilige maatschappij en veiligheid kan niet volledig worden 'gedataficeerd'.

\section{Risico's}

Technologisch gezien zou predictive policing exponentieel verder kunnen groeien. Maar vanuit maatschappelijk en organisatorisch oogpunt zit er nog een rem op. Wil de politie wel zoveel gaan vertrouwen op technologie? Is de organisatie er wel klaar voor? Nemen algoritmen en robots het werk van agenten op diverse vlakken zo meteen over? En 
wat zijn eigenlijk de juridische en ethische haken en ogen? $100 \%$ betrouwbare voorspellingen zijn immers een illusie; of nemen we een foutmarge voor lief en worden onschuldige burgers opgesloten? ${ }^{4}$ Dit zijn relevante vragen die beantwoord moeten worden. Wij zien de voordelen van predictive policing, omdat de politie hiermee efficiënter en effectiever op de juiste plaats ingezet kan worden. Maar wij zien ook risico's. We benoemen er een aantal.

Ten eerste kan predictive policing het risico in zich hebben dat de politie straks allerlei mensen gaat oppakken om vervolgens te zeggen: ja, dat moest van onze algoritmen. Straks worden we door Facebook bij de politie aangegeven voordat we ook maar iets hebben gedaan. Of je wordt staande gehouden terwijl je geheel onschuldig met een gereedschapskist door een buurt loopt waar statistisch gezien op dat moment veel wordt ingebroken. Dan heb je als burger ineens veel uit te leggen. De rechter zal hier vanuit de onschuldpresumptie geen genoegen mee nemen en om bewijs vragen op basis waarvan het algoritme tot de voorspelling is gekomen en vragen naar de reden waarom de politie dat advies heeft opgevolgd. Daarom zijn en blijven de kennis en kunde van de ervaren politieagent leidend. Hij zal moeten beoordelen hoeveel waarde en bewijswaarde kan worden toegekend aan een voorspelling van het systeem en hoeveel aanvullend bewijs is vereist. Dat brengt ons bij een tweede risico, dat het systeem te complex wordt en niet meer door mensen wordt begrepen. Algoritmen vangen echter geen boeven. Dat doen mensen van vlees en bloed. Zonder mensen sta je nergens met intelligence, en al helemaal in de huidige fase van predictive policing waarin alles nog in de kinderschoenen staat.

Human in the loop by design is de essentie van het principe dat wij voorstellen, omdat we de mens als belangrijkste schakel in elke toepassing van predictive policing zien. Alle menselijke schakeltjes moeten ingebakken zitten in het ontwerp van predictive policing. denk aan de analisten, de leiding, de beleidsmakers en de agenten op straat. Hoewel de menselijke schakel onder druk staat in de huidige informatiemaatschappij, zijn veel data die de politie nu gebruikt nog steeds door mensen verzameld, verwerkt en in context geplaatst. Analisten doen vervolgens diverse interpretatieslagen en mensen nemen beslui-

4 Zie voor een overzicht van de risico's van predictive policing het recente artikel van Kaya Bouma, 'Buienradar voor boeven' in De Groene Amsterdammer, www.groene.nl/artikel/ buienradar-voor-boeven. Over de risico's van etnisch profileren verscheen recent een artikel van Marc Schuilenburg op www.socialevraagstukken.nl/etnisch-profileren-is-onderdeel -van-vooringenomen-criminaliteitsbeleid. 
ten op basis van deze adviezen, waarna maatregelen door mensen worden genomen, die vervolgens weer door mensen worden beoordeeld op hun effectiviteit. Politiemensen zijn daarom in onze visie de belangrijkste schakel: het systeem doet de basiszaken, de mens bepaalt wat ermee gebeurt. Een voorspelling is derhalve dus geen bindend advies, want mensen zijn slimmer dan een systeem dat alleen met data werkt. Totdat het moment van singularity aanbreekt, waarbij computers niet alleen sneller of accurater kunnen rekenen, maar ook creatiever, slimmer en bewuster zijn dan mensen. Dat duurt nog minstens twee decennia en zelfs dan is het de vraag of je iets dergelijks in handen van een machine wilt leggen, want dan komt de 'gedachtepolitie' uit Minority Report wel heel dichtbij.

De menselijke factor levert een derde risico op: dat de data in systemen een gekleurd beeld geven (zogenoemde bias) en algoritmen dus gekleurde voorspellingen zullen doen. De voorspelling is zo goed als de data eronder. Wordt het systeem gevoed met vooroordelen ten aanzien van bevolkingsgroepen of etnische afkomst, dan zal dat zijn effect hebben op de resultaten. Daarom is het van belang dat de politie niet alleen op voorspellingen gaat varen en belangrijke beslissingen alleen daarop gaat baseren. Tunnelvisie ligt dan op de loer, een bekend dilemma in het politiewerk. Dit risico zal alleen maar toenemen als het systeem complexer wordt en kennis over de werking afneemt. Wij pleiten daarom voor transparantie. Het moet inzichtelijk zijn hoe de systemen en hun algoritmen werken.

Een vierde risico is dat leveranciers die transparantie niet geven omdat hun concurrentiepositie dan gevaar loopt. Toch zal de maatschappij of de wet wellicht gaan eisen dat algoritmen volledig transparant zijn, want waarom ben je aangehouden, of kwam de politie eigenlijk zelf op jouw spoor? Dat dit belangrijk is, bewijst het grappige voorbeeld van de Miss America-verkiezingen (Hiltzik 2014). Zo kun je het aantal moorden met behulp van stoom of hete vloeistoffen al jarenlang perfect voorspellen door middel van de leeftijd van de Miss America van dat jaar. Algoritmen zijn dom, voeren uit wat er van ze wordt gevraagd en leggen verbanden tussen gebeurtenissen, hoe vreemd een dergelijke relatie ook is. Dergelijke 'fouten' kunnen desastreuze gevolgen hebben, dat hoeft geen betoog.

Een vijfde risico is dat de predictive policing-systemen informatie platslaan tot vakjes en cirkeltjes op een kaart, terwijl academici al honderden jaren onderzoek doen naar waarom mensen crimineel worden en 
hoe ze zich dan gedragen. Om deze kennis, maar ook die van analisten en politiemensen op straat, toe te kunnen voegen moet vóór de implementatie expliciet worden nagedacht over hoe dit ingebakken kan worden in het systeem of in aanvullende processen.

Privacy is een zesde risico. Enerzijds omdat voorspellend politiewerk inbreuk kan maken op de persoonlijke leefomgeving van mensen. Zo kreeg de politie van Chicago veel kritiek op de preventieve huisbezoeken die zij aflegde bij veelplegers (Stroud 2014). Anderzijds zijn er veel gegevens bekend die ertoe doen en voorspellingen beter maken, maar die niet gebruikt of gekoppeld mogen worden om redenen van privacy.

Als laatste risico noemen we de valkuil om vooral te blijven werken aan technologische ontwikkeling en betere computervoorspellingen, terwijl het veel belangrijker is om na te denken over de vraag hoe de politie effectief aan de slag kan gaan met enigszins betrouwbare voorspellingen. De crux zit in het slim regelen van de operationele inzet en slimme interventies.

\section{Prescriptive policing}

Het zo goed mogelijk voorspellen van misdrijven is geen doel op zich. Het gaat erom dat ze worden voorkomen. Om daar inzicht in te krijgen zal de politie het effect van een voorspelling en de daaropvolgende inzet moeten gaan meten. Op die manier leert de politie welke inzet het beste werkt in welke situatie. Daarmee verschuift het politiewerk van predictive policing naar effect-led policing. Als die kennis over de effectiviteit van interventies wordt toegevoegd aan het systeem, verschuift het politiewerk van effect-led policing naar prescriptive policing. Het systeem kan dan niet alleen voorspellingen doen, maar op basis van data uit het verleden ook adviseren over welke politie-inzet in de gegeven situatie het meest effectief zal zijn.

Prescriptive policing werkt alleen als het is toegespitst op een specifiek gebied. Als het systeem kan bepalen waarom iets op sommige plaatsen wel werkt en op andere plaatsen niet, dan kan dat geëxtrapoleerd worden naar andere gebieden. Zonder de effectiviteit van elke interventie in dat specifieke vakje te bepalen kan het systeem inschatten wat waarschijnlijk wel of niet zal werken. Daarvoor moeten wel de relevante kenmerken van een gebied bekend zijn, en de kenmerken van 
interventies. Misschien werkt patrouilleren met de auto niet, maar met de fiets wel. Of zijn er specifieke agenten die naast patrouilleren ook andere acties ondernemen die zorgen dat er wel of geen effect is. Dat maakt prescriptive policing moeilijker, maar tegelijkertijd ook veel waardevoller. Het biedt de mogelijkheid om de jarenlange kennis en ervaring in een context te plaatsen en deze te herhalen daar waar de context gelijk is. Daarbij is het van belang dat een dergelijk systeem niet dicteert wat er moet gebeuren. Zelfs als het systeem denkt dat de context gelijk is, dan nog moeten agenten, analisten, leiding of beleidsmakers vertrouwen op hun jarenlange ervaring en kennis, helemaal aangezien een dergelijk systeem niet de creativiteit heeft om iets nieuws te verzinnen. Het kan enkel de lessen uit het verleden zo goed mogelijk vertalen. De uitkomst mag daarom hoogstens worden gezien als een suggestie die de basis moet vormen voor een beslissing of discussie. De mens blijft wat ons betreft de belangrijkste schakel in het hele proces. Eerder in dit artikel haalden we al het principe 'human in de loop by design' aan. Ook is er een juridisch argument om dit principe toe te passen: de Wet bescherming persoonsgegevens stelt in artikel 42 lid 1 dat 'niemand kan worden onderworpen aan een besluit waaraan voor hem rechtsgevolgen zijn verbonden of dat hem in aanmerkelijke mate treft, indien dat besluit alleen wordt genomen op grond van een geautomatiseerde verwerking van persoonsgegevens bestemd om een beeld te krijgen van bepaalde aspecten van zijn persoonlijkheid'.

\section{Implementatie}

Het doel van predictive en prescriptive policing is niet méér boeven vangen, maar misdrijven voorkomen door agenten effectief preventief in te zetten. Dat vergt een cultuuromslag, waarbij het voorkomen van slachtoffers voortaan centraal staat. Het 'reactief en op heterdaad oppakken' verandert in 'proactief voorkomen'. Deze omslag vraagt om sterk intern leiderschap en sturing. Ook zullen de prestatie-indicatoren van de politie moeten worden aangepast: het gaat niet meer om het behalen van bepaalde streefcijfers, maar om de effectiviteit van politieoptreden. De politie wordt niet meer beloond voor haar inzet, maar voor het effect dat zij bereikt. 
De implementatie van beide vormen van policing gaat echter niet alleen over de organisatiecultuur, maar ook over politiemensen, hun competenties en hun samenwerking met de voorspellende software. Daarnaast gaat het over processen, taken, besluitvorming en manier van leidinggeven. Verder zal tijdens de implementatie veel aandacht uitgaan naar de juiste informatiebronnen en integriteit van data. Tot slot speelt techniek een rol in de implementatie, waarbij de ICT-architectuur ingericht moet worden op deze nieuwe werkwijze, de juiste software geselecteerd en aangeschaft moet worden en agenten op straat de juiste tools krijgen aangereikt.

Alles hangt met elkaar samen. Daarom vraagt de implementatie om een integrale benadering van doel, mens en organisatie, proces, informatie en techniek. Daarbij onderscheiden we vier implementatieniveaus: intelligence-led policing (informatiegestuurd optreden), predictive policing (voorspellen), effect-led policing (effectmeting) en prescriptive policing (contextgestuurde adviezen). Deze vier niveaus hebben we in dit artikel toegelicht.

\section{Discussie}

In dit artikel hebben we laten zien wat predictive policing inhoudt en welke mogelijkheden het biedt. De technologie staat nog in de kinderschoenen, maar de ontwikkelingen gaan razendsnel. De Verenigde Staten lopen hierin voorop. De Nederlandse politie heeft inmiddels de eerste stappen gezet om van informatiegestuurd politiewerk te komen tot voorspellend politiewerk. We hebben ook laten zien dat er risico's verbonden zijn aan deze nieuwe werkwijze. In ons boek Van predictive naar prescriptive policing (Smit e.a. 2016) gaan we daar verder op in. Wij bevelen daarom aan om niet klakkeloos voorspellende software te implementeren in het politieproces, maar eerst te discussiëren over het doel en de mate waarin de software het politiewerk kan gaan ondersteunen. Zorg er vervolgens voor dat deze nieuwe werkwijze gepaard gaat met juridische, ethische en organisatorische waarborgen en start daarna met kleinschalige experimenten die opgeschaald kunnen worden tot landelijk niveau. Onderschat de veranderingen niet die predictive policing met zich meebrengt. Dat vraagt om een goede overdenking en om draagvlak binnen en buiten de politieorganisatie. 


\section{Literatuur}

\section{Aldax 2015}

M. Aldax, 'Richmond police chief says department plans to discontinue "predictive policing" software', 24 juni 2015, http:// richmondstandard.com/2015/06/ richmond-police-chief-saysdepartment-plans-to-discontinue -predictive-policing-software.

\section{Basulto 2014}

D. Basulto, 'Relax, the futuristic pre-crime system of "Minority Report" is still a long way from becoming reality', 6 november 2014, www.washingtonpost.com/ news/innovations/wp/2014/11/ 06/relax-the-futuristic-pre-crime -system-of-minority-report-isstill-a-long-way-from-becomingreality.

\section{Greenburg 2009}

Z.O. Greenburg, 'America's most dangerous cities', Forbes Magazine 23 april 2009.

\section{Hiltzik 2014}

M. Hiltzik, 'See some hilarious charts showing that correlation is not causation', Los Angeles Times 12 mei 2014, www.latimes.com/ business/hiltzik/la-fi-mh-seecorrelation-is-not-causation -20140512-column.html.

\section{Kent Police 2013}

Kent Police, PredPol operational review - Initial findings, Kent: Corporate Services, Analysis Department, Kent Police 2013, www.statewatch.org/docbin/uk -2013-11-kent-police-pp-report. pdf.

\section{Littooij 2015}

A. Littooij, 'Brandweerradar' (J. D. Award, interviewer), 2015.

\section{Mohler e.a. 2015}

G. Mohler, M. Short, S. Malinowski, M. Johnson, G. Tita, A. Bertozzi \& P. Brantingham, 'Randomized controlled field trials of predictive policing', Journal of the American Statistical Association (110) 2015, afl. 512, p. 1399-1411.

\section{Nucleus Research 2010}

Nucleus Research, IBM SPSS ROI Case Study: Memphis Police Department (Document K31), Boston, MA: Nucleus Research, Inc. 2010.

\section{Orwell 1949}

G. Orwell, Nineteen Eighty-Four, New York: New American Library 1949.

\section{Perry e.a. 2013}

Q. Perry, B. McInnis, C. Price, S. Smith \& J. Hollywood, Predictive policing - The role of crime forecasting in law enforcement operations, Santa Monica, CA: Rand Corporation 2013. 


\section{Smit 2014}

S. Smit, 'Computermodel voorspelt overlast in woonwijken - en wanneer die uitblijft', Secondant 30 april 2014.

\section{Smit e.a. 2016}

S. Smit, A. de Vries, R. van Kleij \& H. van Vliet, Van predictive policing naar prescriptive policing, Den Haag: TNO 2016.

\section{Stroud 2014}

M. Stroud, 'The minority report: Chicago's new police computer predicts crimes, but is it racist?', The Verge 19 februari 2014.

\section{Van Weerdt \& De Vries 2014}

C. van Weerdt \& A. de Vries, Dienstverlening verbeteren met Big Data. Een verkenning voor gemeenten. Den Haag: TNO 2014.

\section{Willems \& Doeleman 2014}

D. Willems \& R. Doeleman, 'Criminaliteits Anticipatie Systeem', het Tijdschrift voor de Politie 2014, p. 39-42.

\section{Williams 2006}

A. Williams, 'Blue C.R.U.S.H.

walks its beat among community organizations', Memphis Daily News 16 november 2006. 